\title{
A "Synaptoplasmic Cistern" Mediates Rapid Inhibition of Cochlear Hair Cells
}

\author{
Maria Lioudyno, ${ }^{1}$ Hakim Hiel, ${ }^{1}$ Jee-Hyun Kong, ${ }^{2}$ Eleonora Katz, ${ }^{3}$ Erik Waldman, ${ }^{1}$ Suchitra Parameshwaran-Iyer, ${ }^{1}$ \\ Elisabeth Glowatzki, ${ }^{1}$ and Paul A. Fuchs ${ }^{1}$ \\ ${ }^{1}$ The Cochlear Neurotransmission Laboratory, Center for Hearing and Balance, Department of Otolaryngology-Head and Neck Surgery, and ${ }^{2}$ Department \\ of Neuroscience, Johns Hopkins University School of Medicine, Baltimore, Maryland 21205-2195, and ${ }^{3}$ Instituto de Investigaciones en Ingenieria Genetica y \\ Biologia Molecular, Consejo Nacional de Investigaciones Científicas y Técnicas, Universidad de Buenos Aires, Buenos Aires 1428, Argentina
}

Cochlear hair cells are inhibited by cholinergic efferent neurons. The acetylcholine (ACh) receptor of the hair cell is a ligand-gated cation channel through which calcium enters to activate potassium channels and hyperpolarize the cell. It has been proposed that calciuminduced calcium release (CICR) from a near-membrane postsynaptic store supplements this process. Here, we demonstrate expression of type I ryanodine receptors in outer hair cells in the apical turn of the rat cochlea. Consistent with this finding, ryanodine and other store-active compounds alter the amplitude of transient currents produced by synaptic release of ACh, as well as the response of the hair cell to exogenous ACh. Like the sarcoplasmic reticulum of muscle, the "synaptoplasmic" cistern of the hair cell efficiently couples synaptic input to CICR.

Key words: acetylcholine; calcium; cochlea; hair cell; inhibition; nicotinic

\section{Introduction}

Intracellular calcium stores participate in cellular activities ranging from excitability to gene transcription (Berridge, 1998). Calcium stores can influence presynaptic transmitter release (Krizaj et al., 1999; Llano et al., 2000) and may modulate postsynaptic plasticity (Rose and Konnerth, 2001; Lelli et al., 2003). During excitation-contraction of muscle, tight coupling of voltage-gated calcium channels to ryanodine receptors (RyRs) in the sarcoplasmic reticulum (SR) mediates calcium-induced calcium release (CICR). An intimate association of SR with the plasma membrane ensures the efficacy of CICR. In cochlear hair cells, an SR-like cistern is coextensive with efferent synaptic contacts (Saito, 1983). Intriguingly, the efferent synapse of the hair cell also may use CICR but here to activate calcium-dependent potassium channels for inhibition. We refer, therefore, to the "synaptoplasmic" cistern of the hair cell to recognize this analogy to sarcoplasmic reticulum of muscle.

The efferent synapse of the hair cell is mediated by nicotinic acetylcholine (ACh) receptors (nAChRs) $\alpha 9$ and $\alpha 10$ (Elgoyhen et al., 1994, 2001). These pass an inward cation current followed within milliseconds by the activation of calcium-dependent potassium channels (Fuchs and Murrow, 1992; Blanchet et al., 1996; Evans, 1996; Nenov et al., 1996; Glowatzki and Fuchs, 2000; Ol-

Received Sept. 6, 2004; revised Nov. 5, 2004; accepted Nov. 5, 2004.

This work was supported by National Institute for Deafness and Communication Disorders-National Institutes of Health Grants R01 DC01508 and P30 DC05211.

Correspondence should be addressed to Paul Fuchs, Johns Hopkins University School of Medicine, 720 Rutland Avenue, Traylor Building 521, Baltimore, MD 21205-2195. E-mail: pfuchs@bme.jhu.edu.

M. Lioudyno's present address: Department of Physiology/Biophysics, University of California at Irvine, Irvine, CA 92697-4561.

D01:10.1523/JNEUROSCI.3674-04.2004

Copyright $\odot 2004$ Society for Neuroscience $\quad$ 0270-6474/04/2411160-05\$15.00/0 iver et al., 2000), providing one of the few certified postsynaptic functions for nonmuscle, neuronal nicotinic receptors. Thus, as in skeletal muscle, nAChRs trigger a subsequent calciumdependent process in hair cells. Some evidence suggests that internal calcium stores might participate in the cholinergic response of the hair cell (Kakehata et al., 1993; Evans et al., 2000). Furthermore, cochlear perfusion with agents that affect calcium stores alters efferent inhibition in vivo (Murugasu and Russell, 1996; Sridhar et al., 1997). At the same time, the voltage dependence (Martin and Fuchs, 1992) and time course of the cholinergic response (Oliver et al., 2000) imply that potassium-channel gating depends on calcium influx through the nAChRs. Calciuminduced calcium release from the synaptoplasmic cistern reconciles most of these observations.

The present study demonstrates ryanodine receptor expression in hair cells of the rat cochlea. Also, ryanodine and other store-active compounds alter the potassium currents evoked in hair cells by ACh. These results suggest that the adjoining synaptoplasmic cistern acts as a tightly coupled calcium store to convert rapid nicotinic excitation into inhibition. Thus, cholinergic inhibition of hair cells provides evidence of a role for calcium stores in rapid postsynaptic transmission.

\section{Materials and Methods}

Animal protocols were approved by the Johns Hopkins University Animal Care and Use Committee. Sprague Dawley rats, 3-4 weeks of age, were overdosed and decapitated. The organ of Corti was exposed, and the apical turn was removed for cell isolation or recording.

Reverse-transcriptase PCR. Approximately 50 outer hair cells (OHCs) were drawn into glass capillaries (into $10 \mu \mathrm{l}$ of RNAase-free buffer). In some cases, several hundred OHCs and Deiters' cells were combined. RNA extraction, reverse translation, and amplification followed established protocols (Hiel et al., 2000). 
Specific primers and product size for $\mathrm{IP}_{3}$ receptor $\left(\mathrm{IP}_{3} \mathrm{R}\right)$ and $\mathrm{RyR}$ isoforms were based on the following rat sequences in GenBank: $\mathrm{IP}_{3} \mathrm{R} 1$, $5^{\prime}$ gcggccctggctctgattctgg $3^{\prime}$ and $3^{\prime}$ 'gggecacatgagccacctcag5' (643 bp); $\mathrm{IP}_{3} \mathrm{R} 2,5^{\prime}$ 'cgttcacccgagggtaccgag $3^{\prime}$ and $3^{\prime}$ 'tcggtgcatcgagagtccggg5' (852 bp); $\mathrm{IP}_{3} \mathrm{R} 3,5^{\prime}$ acccgcaatggccgctccatcc $3^{\prime}$ and $3^{\prime}$ actcggtgcatcgagagccccg $5^{\prime}$ (689 bp); RyR1, 5' accctccaccaggcctgctgac $3^{\prime}$ and 3'agagcaggggctacggtggtgg5' (425 bp); RyR1nested, 5' gggctcctggctgtagtggtct3' and $3^{\prime}$ 'tggc'gggcctgggggtgtatg5' (159 bp); RyR2, 5' agcctgaggtccccgagtcagca ${ }^{\prime}$ and 3'gtggtcagacagggtgaccgga5' (491 bp); RyR3, 5' ggagcagagcgatcgctgaact3' and 3' ggacgaccagggagtcgagagg5' (643 bp).

Negative control reactions replaced reverse transcriptase (RT) with water. PCR with gene-specific primers used a "touch-down" protocol. PCR products were sequenced to confirm gene identity.

In situ hybridization. In situ hybridization experiments used previously published protocols (Hiel et al., 1996). Briefly, the temporal bones of postnatal rat pups were fixed, decalcified, and embedded for cryosectioning. Postfixed, acetylated, and dehydrated $14 \mu \mathrm{m}$ cryosections were hybridized with ${ }^{35} \mathrm{~S}$-labeled riboprobe (989 bp; $1.2 \times 10^{6} \mathrm{cpm} / \mathrm{slide}$ ) for $16 \mathrm{hr}$ at $56^{\circ} \mathrm{C}$. After high-stringency washes and dehydration, tissue sections were coated with photographic emulsion NBT-2 (Eastman Kodak, Rochester, NY) and developed for $2-5$ weeks at $4^{\circ} \mathrm{C}$.

Electrophysiology. Whole-cell, tight-seal voltage-clamp recordings were made from first- and second-row $\mathrm{OHCs}$ in the apical turn of the rat organ of Corti. The extracellular solution contained the following (in $\mathrm{mm}$ ): $4 \mathrm{KCl}, 150 \mathrm{NaCl}, 0.9 \mathrm{MgCl}_{2}, 1.3 \mathrm{CaCl}_{2}, 0.7 \mathrm{NaH}_{2} \mathrm{PO}_{4}, 5.6$ glucose, 10 HEPES, 1 ascorbate, $\mathrm{pH}$ 7.4. The pipette solution contained the following (in mM): $115 \mathrm{KCl}, 20 \mathrm{~K}_{2} \mathrm{SO}_{4}, 3.5 \mathrm{MgCl}_{2}, 0.1 \mathrm{CaCl}_{2}, 5 \mathrm{EGTA}, 5$ HEPES, $2.5 \mathrm{Na}_{2} \mathrm{ATP}, 6$ glucose, $\mathrm{pH}$ 7.2. To prevent small conductance (SK) current, intracellular EGTA was replaced with bis(2aminophenoxy)ethane- $N, N, N^{\prime}, N^{\prime}$-tetra-acetic acid (BAPTA). In some experiments, internal potassium was replaced with cesium to reduce delayed rectifier potassium currents. The divalent concentration of the extracellular solution was reduced to maximize current flow through the hair-cell AChR (Weisstaub et al., 2002) and contained the following (in mM): $4 \mathrm{KCl}, 150 \mathrm{NaCl}, 0.5 \mathrm{CaCl}_{2}, 0.7 \mathrm{NaH}_{2} \mathrm{PO}_{4}, 5.6$ glucose, 10 HEPES, 1 ascorbate. All drugs were obtained from Sigma Chemical (St. Louis, $\mathrm{MO}$ ). Average cell capacitance was $22.4 \pm 4.3 \mathrm{pF}$ (mean $\pm \mathrm{SD}$ ). Solution changes were made by a gravity-fed multichannel glass pipette positioned $\sim 300 \mu \mathrm{m}$ from the cell. Recordings were made at room temperature $\left(22-25^{\circ} \mathrm{C}\right)$. All means include SEs unless otherwise specified.

\section{Results}

\section{Ryanodine receptor type 1 in hair cells}

The efferent synaptic specialization of cochlear hair cells includes a postsynaptic endoplasmic reticulum, referred to here as the synaptoplasmic cistern (Fig. 1a). This cistern is coextensive with the micrometers-long efferent contact, aligned just $30 \mathrm{~nm}$ from the postsynaptic plasma membrane, suggesting functional coupling to AChRs. To identify potential activators of what may be a synaptic calcium store, RT-PCR was conducted on whole cochlear tissue from adult rat with primers for each of the three known RyR and $\mathrm{IP}_{3} \mathrm{R}$ genes. All six gene products could be amplified. When OHCs and Deiters' cells microdissected from the apical organ of Corti were used as template, all but RyR2 were amplified (Fig. $1 b$ ) in repeated experiments. However, with $\sim 50$ $\mathrm{OHCs}$ as template for RT-PCR, only RyR1 primers reproducibly gave a product (Fig. $1 b$, right). $\mathrm{IP}_{3} \mathrm{R} 1$ was detected once in five experiments. Each product band was sequenced to confirm identity. Sequential rounds of PCR for the other gene products failed to produce visible bands from OHCs.

Expression of RyR1 in OHCs also was demonstrated in the apical turn of the organ of Corti by in situ hybridization with a subtype-specific riboprobe (Fig. 1, $c$ and $d$, presents the same cochlear section, with location of all hair cells indicated by an overlay in Fig. $1 c$ and dotted outlines of fewer cells in Fig. 1d). After 2-5 weeks exposure, reacted silver grains could be seen concentrated over the synaptic pole of OHCs, but not inner hair
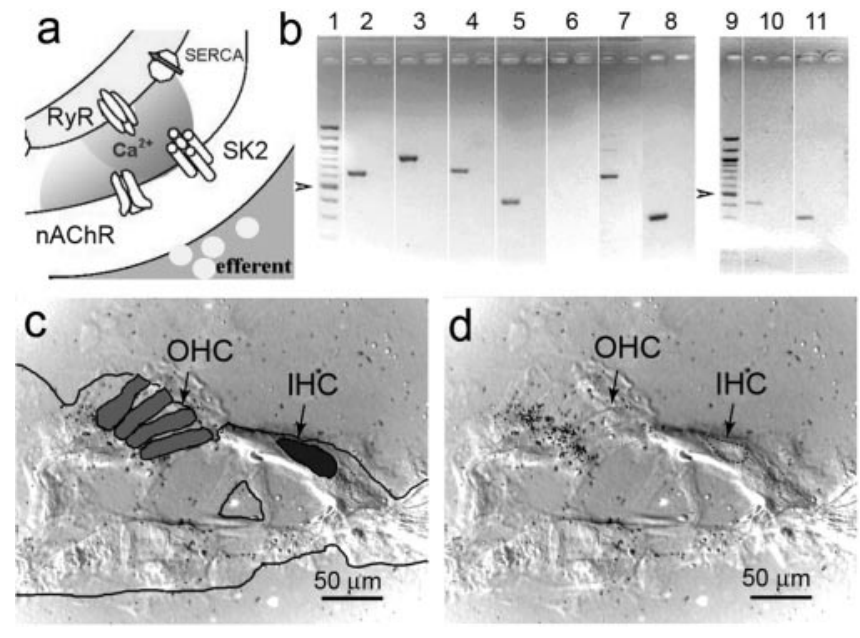

Figure 1. Ryanodine receptors in hair cells. $a$, Schematic of the efferent synapse and synaptoplasmic cistern. $b, R T-P C R$ for the three RyRs and $\mathbb{P}_{3} R$ reveal that all but RyR2 was found in microdissected samples of $\mathrm{OHCs}$ and Dieters' cells. Lanes 1 and 9, 100 bp ladder (arrow at 500 bp). Samples 2-7 (run concurrently as a single gel), Combined $0 H C s$ and Deiters' cells, $I_{3} R 1$, $I_{3} R 2$, IP $R 3$, RyR1, RyR2, and RyR3 primers, respectively, plus and minus $R T$ each lane. Sample 8, $\alpha 9$ positive control for $\mathrm{OHCs}$. When $\mathrm{OHCs}$ alone were used as template, only RyR 1 was found (sample 10), along with the positive $\alpha 9$ control (sample 11). c, A cross section of the adult rat organ of Corti is highlighted to show the position of $\mathrm{OHCs}$ and IHCs. The section outline, tunnel of Corti, four OHCs, and one IHC are drawn in d, the same cross section as in c. Black dots are precipitated silver grains attributable to emission from radioactive in situ probe to RyR1. OHCs, but not IHCS, reveal RyR1 in apical turns of the adult rat cochlea.

cells (IHCs), in apical turns of the adult rat cochlea (Fig. 1d). Sense controls produced no specific labeling, whereas the same antisense probe labeled rat cerebellar Purkinje cells as a positive control (data not shown).

\section{Calcium stores and membrane currents evoked by exogenous $\mathrm{ACh}$}

Functional evidence for ryanodine-sensitive calcium stores in cholinergic inhibition was obtained using whole-cell voltageclamp recording of OHCs in an excised apical turn of the 3- to 4-week-old rat cochlea. Two types of response were studied: membrane currents evoked by application of exogenous ACh and transient synaptic currents occurring spontaneously or after application of high-potassium saline. Calcium stores pharmacology was explored more extensively using the $\mathrm{OHC}$ response to exogenous ACh.

ACh $(100 \mu \mathrm{M})$ applied from the perfusion pipette evoked an outward potassium current at $-30 \mathrm{mV}$ (Fig. 2), as described previously in isolated OHCs (Blanchet et al., 1996; Evans, 1996; Nenov et al., 1996). This is the calcium-dependent potassium current that is triggered by nAChR gating in the hair cell. At -30 $\mathrm{mV}$ holding potential, only the later, larger potassium current is visible on the illustrated time scale. The "two-channel" ionic mechanism of the OHC cholinergic response was confirmed by pharmacological blockade and voltage dependence, as described previously (Martin and Fuchs, 1992; Glowatzki and Fuchs, 2000).

Exposure of OHCs to cyclopiazonic acid (CPA), a membranepermeant inhibitor of endoplasmic calcium ATPases (SERCAs) that maintain intracisternal calcium (Goeger et al., 1988), suppressed the response to exogenous ACh (Fig. $2 a$ ). This effect was reversible and reproducible in five of five OHCs. Presumably, suppression of endoplasmic calcium pump activity by CPA led to an emptying of calcium stores and hence reduction in these responses of the $\mathrm{OHC}$ to seconds-long application of ACh. 


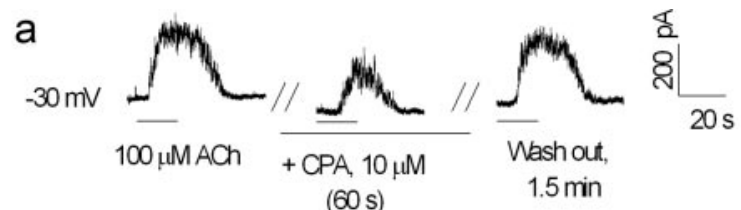

$(60 \mathrm{~s})$

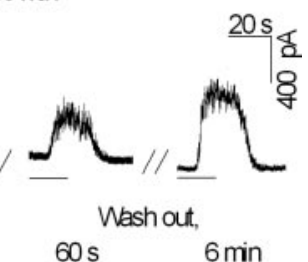

(5s)

$(8 \mathrm{~min})$

$60 \mathrm{~s}$

$6 \mathrm{~min}$
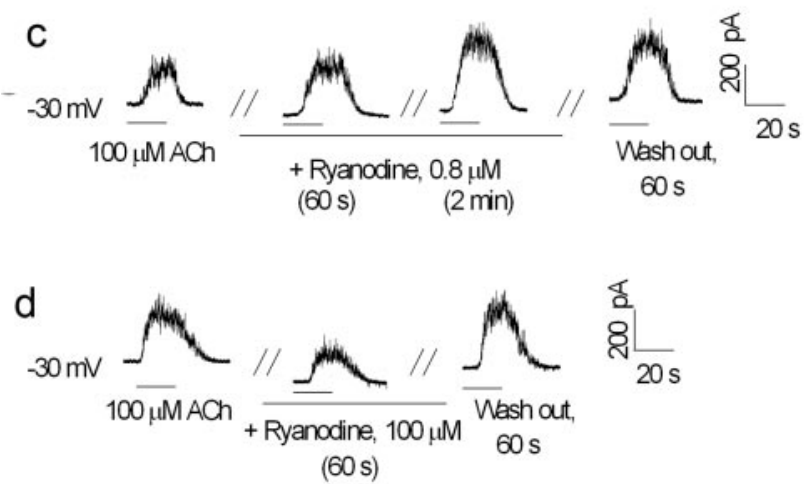

e

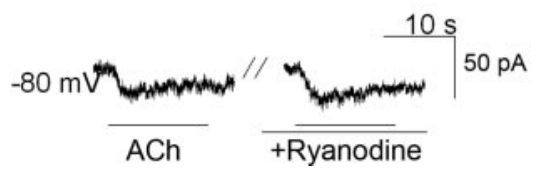

Figure 2. Intracellular calcium store modulators on ACh-evoked potassium currents in $\mathrm{OHCS}$. All effects were observed at $-30 \mathrm{mV}$. $a$, The SERCA antagonist CPA $(10 \mu \mathrm{m})$ reduced the ACh-evoked current by $43 \pm 6 \%$ ( 5 of $5 \mathrm{OHCs}$ ). $b$, Caffeine $(5 \mathrm{~mm}$ ) produced an initial augmentation ( $14 \pm 4 \% ; 3$ of $4 \mathrm{OHCS}$ ) followed by a gradual reduction of the ACh-evoked current ( $65 \pm$ $6 \%$; SE, 4 of $40 \mathrm{OHCs}$ ). c, At $0.5-1 \mu \mathrm{M}$, ryanodine facilitated the ACh response by $60 \pm 29 \%$ ( 6 of $6 \mathrm{OHCs}$ ). $d$, The amplitude of the ACh-evoked response was reduced by $39 \pm 4 \%$ ( 6 of $6 \mathrm{OHCs}$ ) in the presence of $100 \mu \mathrm{m}$ ryanodine. $e$, Ryanodine $(100 \mu \mathrm{m})$ did not reduce the isolated nAChR current in three BAPTA-buffered OHCs.

To identify potential mechanisms of calcium store activation, ligands for different classes of calcium store release channels were examined. The membrane-permeant $\mathrm{IP}_{3}$ receptor antagonist xestospongin C (Gafni et al., 1997) at 100-300 nM had inconsistent effects on the ACh-evoked current in eight OHCs. In contrast, caffeine, which promotes RyR opening (Pessah et al., 1987), initially facilitated, then gradually suppressed, the response to ACh in four OHCs (Fig. 2b). Moreover, caffeine was equally effective even at $300 \mu \mathrm{M}$, consistent with the presence in OHCs of the caffeine-sensitive RyR1 isoform (Conklin et al., 2000).

As predicted by the effect of caffeine, ryanodine at $1 \mu \mathrm{M}$ facilitated the response to ACh (Fig. 2c) in six of six OHCs. Conversely, as shown previously (Bull et al., 1989), $100 \mu \mathrm{M}$ ryanodine acted as an antagonist. The response to $100 \mu \mathrm{M}$ ACh was significantly smaller in the presence of $100 \mu \mathrm{M}$ ryanodine (Fig. $2 d$ ) in six of six OHCs. Importantly, $100 \mu \mathrm{M}$ ryanodine caused no significant reduction of cationic currents through the $\mathrm{nAChR}$ of the hair cell (Fig. 2e) when SK gating was prevented by strong internal BAPTA buffering.

\section{Calcium stores and synaptic currents}

Ryanodine $(100 \mu \mathrm{M})$ was bath applied to test its effect on efferent IPSCs in OHCs. The normally biphasic IPSC becomes entirely a

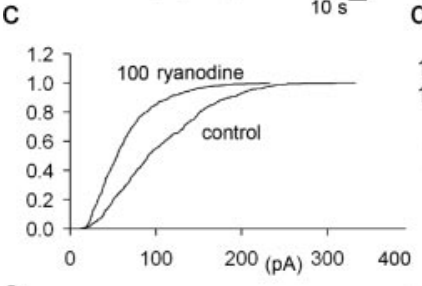

e

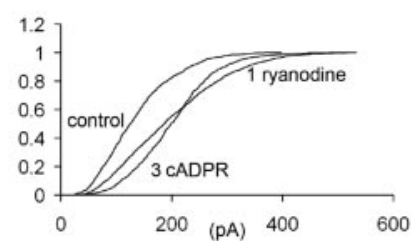

b

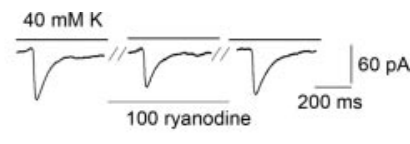

d

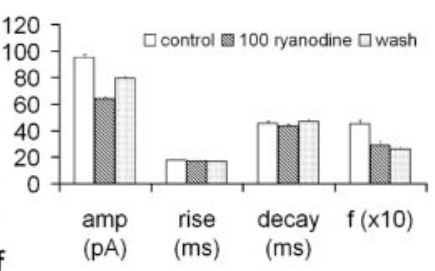

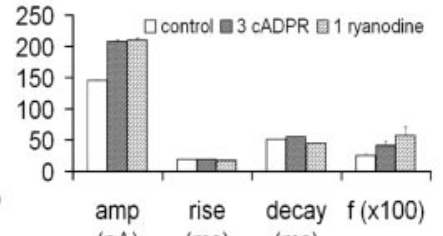

(pA) (ms) (ms)

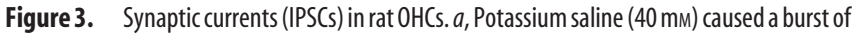
IPSCs.b, Averaged IPSC waveform obtained before $(n=700)$, during $(n=440)$, and after $(n=$ 406) exposure to $100 \mu \mathrm{m}$ ryanodine. C, Cumulative fraction plot of IPSC amplitude. IPSC amplitudes shifted to smaller values in $100 \mu \mathrm{m}$ ryanodine. $d$, IPSC amplitude, but not time course, was changed by $100 \mu \mathrm{m}$ ryanodine. Average peak amplitude was $-95 \pm 2.0 \mathrm{pA}$ ( $n=700 ; 5$ cells) in control, $-64 \pm 1.6 \mathrm{pA}$ ( $n=440 ; 5$ cells) in ryanodine $(6 \mathrm{~min})$, and $-79.4 \pm 2.3 \mathrm{pA}$ ( $n=$ $406 ; 5$ cells) after washing. Rise and decay times of single, well segregated IPSCs showed no effect of ryanodine. The mean $10-90 \%$ rise time was $17.4 \pm 0.5,17.1 \pm 0.5$, and $16.9 \pm 0.5$ msec respectively in control, ryanodine, and wash conditions. Single exponential decay time constants (in milliseconds) were $45.5 \pm 1.8$ in control, $43.4 \pm 1.4$ in ryanodine, and $46.8 \pm 2.3$ after washing. IPSC frequency (f) dropped from 4.5 to $2.9 \mathrm{~Hz}$ in the presence of $100 \mu \mathrm{m}$ ryanodine but did not recover. e, IPSC amplitude distributions shifted to larger values with $1 \mu \mathrm{m}$ ryanodine or $3 \mu \mathrm{M}$ CADPR intracellular. $f$, IPSCs were $-145 \pm 2.3 \mathrm{pA}$ in control $(n=849 ; 17$ haircells), $-207 \pm 2.5 \mathrm{pA}$ in $3 \mu \mathrm{m} \mathrm{CADPR}(n=1446 ; 11$ cells), $-210 \pm 2.5 \mathrm{in} 1 \mu \mathrm{m}$ ryanodine ( $n=883 ; 4$ cells). Rise times (in milliseconds; $10-90 \%$ ) were $18.8 \pm 0.2,18.4 \pm 0.1$, and $17.0 \pm 0.1$. Decay times (in milliseconds) were $51.2 \pm 0.6,54.9 \pm 0.5$, and $44.6 \pm 0.4$. IPSC frequency was $0.25 \mathrm{~Hz}$ in control cells, $0.41 \mathrm{~Hz}$ in CADPR, and $0.57 \mathrm{~Hz}$ in ryanodine. Error bars represent SE.

inward at $-70 \mathrm{mV}$ when high-potassium saline is used to accelerate release from efferent terminals (Fig. $3 a$ ). In the presence of $100 \mu \mathrm{M}$ ryanodine to block CICR (Meissner and el-Hashem, 1992), IPSCs were $\sim 30 \%$ smaller on average (Fig. $3 b$ ) and recovered partially after washing. The effect of ryanodine on IPSC amplitude is further revealed by cumulative fraction plots. These represent the summing up of IPSCs from small to large, expressed as a fraction of the total distribution. The overall amplitude distribution was shifted to lower values (Fig. $3 c$ ) in the presence of $100 \mu \mathrm{M}$ ryanodine. Ryanodine acted similarly on all five cells tested, reducing the mean IPSC amplitude by approximately onethird in each case. The effect of ryanodine was not unique to the high-potassium condition, because an even larger reduction in average amplitude also was found in two cells in which sufficient numbers of outward-going IPSCs could be recorded at $-30 \mathrm{mV}$ in saline containing $4 \mathrm{~mm}$ potassium. In addition to their ryanodine sensitivity, cholinergic IPSPs also were inhibited $\sim 15 \%$ by the ryanodine receptor antagonist 8-bromo-cyclic ADP-ribose (cADPR; $10 \mu \mathrm{M}$ ) (data not shown).

Thus, cholinergic synaptic currents were affected by ryanodine similarly to the response of the hair cell to exogenous ACh, consistent with actions on a postsynaptic calcium store. Nonetheless, bath application of ryanodine leaves open the possibility that the effects on IPSCs could be attributable to presynaptic, as well as postsynaptic, sites of action. For example, mean IPSC 
frequency dropped from 4.5 to $2.9 \mathrm{~Hz}$ in the presence of $100 \mu \mathrm{M}$ ryanodine, although this change was irreversible.

To test specifically for actions on the postsynaptic hair cell, ryanodine receptor agonists were added to the internal pipette solution. The effects of ryanodine or the agonist, cADPR, were assessed by comparing IPSCs from treated cells with those from controls. When recording pipettes contained $1 \mu \mathrm{M}$ ryanodine or 3 $\mu \mathrm{M}$ CADPR, both considered RyR agonists, the IPSC amplitude distribution was shifted to higher values than found in control cells (Fig. $3 e$ ). The mean IPSC amplitude in ryanodine or cADPR was $\sim 40 \%$ greater than in control (Fig. $3 f$ ). Because cADPR is membrane impermeant, it can only have acted on the postsynaptic hair cell. Likewise, it seems unlikely that $1 \mu \mathrm{M}$ ryanodine, although membrane permeant, could progress from the hair cell, across the extracellular space, to reach effective concentrations in adjoining efferent terminals.

In contrast to their effects on amplitude, these store-active compounds had no consistent effect on the time course of IPSCs (Fig. $3 d, f$ ). In all cases, the $10-90 \%$ rise time was $17-18 \mathrm{msec}$. The mean time constant of decay, obtained from a single exponential fit to IPSCs at $-80 \mathrm{mV}$ and ranging from $43-55 \mathrm{msec}$, was slightly shorter after low or high ryanodine and slightly longer in cADPR. Outward-going IPSCs recorded at $-30 \mathrm{mV}$ (in $4 \mathrm{~mm}$ potassium) in two hair cells likewise showed no effect on time course (data not shown).

\section{Discussion}

ACh binds to $\alpha 9 / \alpha 10$-containing nicotinic receptors to cause calcium influx and activation of calcium-activated (SK) potassium channels in vertebrate hair cells. The present data show that the resulting potassium current, whether caused by applied ACh or synaptic release, is altered in amplitude, but not time course, by compounds that act on intracellular calcium stores, presumably the closely associated synaptoplasmic cistern. Because ryanodine, caffeine, and cADPR were effective, but not xestospongin $\mathrm{C}$, an $\mathrm{IP}_{3} \mathrm{R}$ antagonist, CICR by RyRs is the most likely mechanism of store coupling in these OHCs from apical turn of the cochlea. In further support of this hypothesis, expression of the type I RyR in an equivalent population of apical hair cells was demonstrated both by RT-PCR and in situ hybridization. The lack of effect on IPSC time course implies that RyR gating is intimately coupled to opening of the nAChR of the hair cell.

Alternative explanations for the effects of ryanodine also exist. For example, ryanodine added to the external solution also could affect presynaptic calcium stores to alter the average quantal content (Llano et al., 2000) and so the mean amplitude of IPSCs. Although presynaptic actions were not explicitly ruled out in the present work, they would be very unlikely in experiments applying $1 \mu \mathrm{M}$ ryanodine or membrane-impermeant CADPR via the hair-cell patch pipette. Putative presynaptic actions also cannot explain the equivalent effects of ryanodine on the response of the hair cell to exogenous ACh.

Another point to consider is that "lateral cisterns" in OHCs might underlie the present results. These have been suggested previously to support slow efferent effects in the intact cochlea (Sridhar et al., 1997). However, these lateral cisterns seem less likely to modulate the rapid IPSCs studied here. The recording pipettes contained $5 \mathrm{~mm}$ EGTA that would sharply curtail calcium signaling from the relatively distant lateral cisterns. Furthermore, it was shown previously (Fuchs and Murrow, 1992) that the SK currents evoked by ACh in hair cells could only be prevented by the rapid calcium buffer BAPTA, and not by EGTA, implying that calcium rises in a small fraction of a millisecond.
Finally, the striking pattern of RyR1 in situ labeling at the synaptic pole of the OHC places that mRNA near the synaptoplasmic cistern, but far from the lateral cisterns, echoing the topological sorting of mRNAs for synaptic proteins in neurons (Mohr, 1999).

Ryanodine receptor ligands acted similarly on the amplitude of the milliseconds-long IPSCs and the seconds-long ACh responses, suggesting that a postsynaptic calcium store is implicated in the genesis of both signals. However, ryanodine altered mean IPSC amplitude without changing kinetics, a puzzling outcome given that SK channel gating kinetics are calcium dependent (Hirschberg et al., 1998). Could a tightly coupled calcium store account for this feature of the cholinergic response of the hair cell? It would if complexes of nAChRs and RyRs operate as "quantal release units," as proposed for voltage-gated calcium channels and RyRs in cardiac myocytes (Wier and Balke, 1999). In this scheme, nAChR and RyR clusters would activate in an all-or-none manner, providing stereotyped calcium signals for local SK channel activation. Thus, altering the open probability of RyRs with ryanodine or CADPR would change the number of active complexes, but not the dimensions of successful calcium signals, leaving unchanged the calcium-dependent dynamics of potassium-channel gating that dominate the IPSC decay time (Oliver et al., 2000). Likewise, the brief delay between inward and outward components of the biphasic IPSCs could involve RyRs if near-membrane calcium reaches micromolar levels (Zahradnikova et al., 1999). Finally, the bell-shaped steady-state voltage dependence of ACh-evoked SK current (Martin and Fuchs, 1992) may result from tight coupling of RyR gating to calcium influx, as in cardiac myocytes (Rice et al., 1998).

Together, the characteristics of synaptic currents in OHCs would require a participating calcium store to be closely juxtaposed, as is the synaptoplasmic cistern. This endoplasmic organelle is found within $20-30 \mathrm{~nm}$ of the plasma membrane, is coextensive with the efferent contact, and appears to be an obligatory feature of hair-cell cholinergic synapses. Freeze-fracture electron microscopy reveals dense plaques of intramembranous particles in the plasma membrane beneath the cisterns (Gulley and Reese, 1977). Indeed, this ultrastructure and the present results suggest a strong analogy to the SR of muscle. Just as the SR ensures the efficient conversion of nicotinic excitation into muscular force, the synaptoplasmic cistern of the hair cell ensures the rapid activation of calcium-dependent potassium channels to convert nicotinic excitation into synaptic inhibition. Synaptoplasmic cisterns likewise could account for the store-dependent cholinergic inhibition of dorsal septal neurons (Wong and Gallagher, 1989; Sorenson and Gallagher, 1996), and the presence of similar structures in cerebellar neurons and spinal motorneurons (Henkart et al., 1976; Watanabe, 1981) suggests that this may be a still more broadly used synaptic mechanism.

\section{References}

Berridge MJ (1998) Neuronal calcium signaling. Neuron 21:13-26.

Blanchet C, Erostegui C, Sugasawa M, Dulon D (1996) Acetylcholineinduced potassium current of guinea pig outer hair cells: its dependence on a calcium influx through nicotinic-like receptors. J Neurosci $16: 2574-2584$.

Bull R, Marengo JJ, Suarez-Isla BA, Donoso P, Sutko JL, Hidalgo C (1989) Activation of calcium channels in sarcoplasmic reticulum from frog muscle by nanomolar concentrations of ryanodine. Biophys J 56:749-756.

Conklin MW, Ahern CA, Vallejo P, Sorrentino V, Takeshima H, Coronado R (2000) Comparison of $\mathrm{Ca}^{2+}$ sparks produced independently by two ryanodine receptor isoforms (type 1 or type 3). Biophys J 78:1777-1785.

Elgoyhen AB, Johnson DS, Boulter J, Vetter DE, Heinemann S (1994) Alpha 9: an acetylcholine receptor with novel pharmacological properties expressed in rat cochlear hair cells. Cell 79:705-715. 
Elgoyhen AB, Vetter DE, Katz E, Rothlin CV, Heinemann SF, Boulter J (2001) Alpha10: a determinant of nicotinic cholinergic receptor function in mammalian vestibular and cochlear mechanosensory hair cells. Proc Natl Acad Sci USA 98:3501-3506.

Evans MG (1996) Acetylcholine activates two currents in guinea-pig outer hair cells. J Physiol (Lond) 491:563-578.

Evans MG, Lagostena L, Darbon P, Mammano F (2000) Cholinergic control of membrane conductance and intracellular free $\mathrm{Ca}^{2+}$ in outer hair cells of the guinea pig cochlea. Cell Calcium 28:195-203.

Fuchs PA, Murrow BW (1992) Cholinergic inhibition of short (outer) hair cells of the chick's cochlea. J Neurosci 12:800-809.

Gafni J, Munsch JA, Lam TH, Catlin MC, Costa LG, Molinski TF, Pessah IN (1997) Xestospongins: potent membrane permeable blockers of the inositol 1,4,5-trisphosphate receptor. Neuron 19:723-733.

Glowatzki E, Fuchs PA (2000) Cholinergic synaptic inhibition of inner hair cells in the neonatal mammalian cochlea. Science 288:2366-2368.

Goeger DE, Riley RT, Dorner JW, Cole RJ (1988) Cyclopiazonic acid inhibition of the $\mathrm{Ca}^{2+}$-transport ATPase in rat skeletal muscle sarcoplasmic reticulum vesicles. Biochem Pharmacol 37:978-981.

Gulley RL, Reese TS (1977) Freeze-fracture studies on the synapses in the organ of Corti. J Comp Neurol 171:517-543.

Henkart M, Landis DM, Reese TS (1976) Similarity of junctions between plasma membranes and endoplasmic reticulum in muscle and neurons. J Cell Biol 70:338-347.

Hiel H, Elgoyhen AB, Drescher DG, Morley BJ (1996) Expression of nicotinic acetylcholine receptor mRNA in the adult rat peripheral vestibular system. Brain Res 738:347-352.

Hiel H, Luebke AE, Fuchs PA (2000) Cloning and expression of the alpha9 nicotinic acetylcholine receptor subunit in cochlear hair cells of the chick. Brain Res 858:215-225.

Hirschberg B, Maylie J, Adelman JP, Marrion NV (1998) Gating of recombinant small-conductance Ca-activated $\mathrm{K}+$ channels by calcium. J Gen Physiol 111:565-581.

Kakehata S, Nakagawa T, Takasaka T, Akaike N (1993) Cellular mechanism of acetylcholine-induced response in dissociated outer hair cells of guinea-pig cochlea. J Physiol (Lond) 463:227-244.

Krizaj D, Bao JX, Schmitz Y, Witkovsky P, Copenhagen DR (1999) Caffeine-sensitive calcium stores regulate synaptic transmission from retinal rod photoreceptors. J Neurosci 19:7249-7261.

Lelli A, Perin P, Martini M, Ciubotaru CD, Prigioni I, Valli P, Rossi ML, Mammano F (2003) Presynaptic calcium stores modulate afferent release in vestibular hair cells. J Neurosci 23:6894-6903.

Llano I, Gonzalez J, Caputo C, Lai FA, Blayney LM, Tan YP, Marty A (2000) Presynaptic calcium stores underlie large-amplitude miniature IPSCs and spontaneous calcium transients. Nat Neurosci 3:1256-1265.

Martin AR, Fuchs PA (1992) The dependence of calcium-activated potas- sium currents on membrane potential. Proc R Soc Lond B Biol Sci 250:71-76.

Meissner G, el-Hashem A (1992) Ryanodine as a functional probe of the skeletal muscle sarcoplasmic reticulum $\mathrm{Ca} 2+$ release channel. Mol Cell Biochem 114:119-123.

Mohr E (1999) Subcellular RNA compartmentalization. Prog Neurobiol 57:507-525.

Murugasu E, Russell IJ (1996) The effect of efferent stimulation on basilar membrane displacement in the basal turn of the guinea pig cochlea. J Neurosci 16:325-332.

Nenov AP, Norris C, Bobbin RP (1996) Acetylcholine response in guinea pig outer hair cells. II. Activation of a small conductance $\mathrm{Ca}^{2+}$-activated K+ channel. Hear Res 101:149-172.

Oliver D, Klocker N, Schuck J, Baukrowitz T, Ruppersberg JP, Fakler B (2000) Gating of $\mathrm{Ca}^{2+}$-activated $\mathrm{K}+$ channels controls fast inhibitory synaptic transmission at auditory outer hair cells. Neuron 26:595-601.

Pessah IN, Stambuk RA, Casida JE (1987) $\mathrm{Ca}^{2+}$-activated ryanodine binding: mechanisms of sensitivity and intensity modulation by $\mathrm{Mg}^{2+}$, caffeine, and adenine nucleotides. Mol Pharmacol 31:232-238.

Rice JJ, Jafri MS, Winslow RL (1998) Modeling short-term interval-force relations in cardiac muscle. Ann NY Acad Sci 853:345-349.

Rose CR, Konnerth A (2001) Stores not just for storage. Intracellular calcium release and synaptic plasticity. Neuron 31:519-522.

Saito K (1983) Fine structure of the sensory epithelium of guinea-pig organ of Corti: subsurface cisternae and lamellar bodies in the outer hair cells. Cell Tissue Res 229:467-481.

Sorenson EM, Gallagher JP (1996) The membrane hyperpolarization of rat dorsolateral septal nucleus neurons is mediated by a novel nicotinic receptor. J Pharmacol Exp Ther 277:1733-1743.

Sridhar TS, Brown MC, Sewell WF (1997) Unique postsynaptic signaling at the hair cell efferent synapse permits calcium to evoke changes on two time scales. J Neurosci 17:428-437.

Watanabe H (1981) Development of axosomatic synapses of the Xenopus spinal cord with special reference to subsurface cisterns and C-type synapses. J Comp Neurol 200:323-328.

Weisstaub N, Vetter DE, Elgoyhen AB, Katz E (2002) The alpha9alpha10 nicotinic acetylcholine receptor is permeable to and is modulated by divalent cations. Hear Res 167:122-135.

Wier WG, Balke CW (1999) $\mathrm{Ca}^{2+}$ release mechanisms, $\mathrm{Ca}^{2+}$ sparks, and local control of excitation-contraction coupling in normal heart muscle. Circ Res 85:770-776.

Wong LA, Gallagher JP (1989) A direct nicotinic receptor-mediated inhibition recorded intracellularly in vitro. Nature 341:439-442.

Zahradnikova A, Zahradnik I, Gyorke I, Gyorke S (1999) Rapid activation of the cardiac ryanodine receptor by submillisecond calcium stimuli. J Gen Physiol 114:787-798. 